Acta vet. scand. 1984, 25, 436-444.

From the State Veterinary Serum Laboratory, Copenhagen, Denmark.

\title{
EFFECT ON PERINATAL MORTALITY OF A SINGLE SELENIUM INJECTION TO SOWS AND GILTS
}

\author{
By \\ A. Mikél Jensen, P. Thode Jensen, K. Vinther ${ }^{1}$, P. Jessen ${ }^{1}$ \\ and E. W. Skov-Jensen ${ }^{2}$
}

MIKELL JENSEN, A., P. THODE JENSEN, K. VINTHER, P. JESSEN and E. W. SKOV-JENSEN: Effect on perinatal mortality of a single selenium injection to sows and gilts. Acta vet. scand. 1984, 25, 436-444. - Selenium treatment of pregnant sows and gilts was conducted as a double-blind placebo-controlled study in 5 commercial herds with a total of 350 sows and gilts (Danish Landrace, Yorkshire and Landrace-Yorkshire crossbreeds.). At 3-6 weeks before farrowing the animals were injected once intramuscularly with either Na-selenite $\mathbf{( 0 . 0 5}$ $\mathrm{mg}$ Se per $\mathrm{kg}$ ) or placebo. Blood samples were taken immediately before treatment and once again at 3-6 weeks after farrowing, to evaluate the Se status. The productivity of the sows and gilts was recorded.

Within herds there was no pretreatment difference in Se status between the two treatment groups, while a considerable variation was seen among herds. After farrowing there were only minor differences in Se status between the treatment groups, whereas the variation among herds persisted.

Overall, no effect of the Na-selenite injection was seen, in that there was no difference in number of liveborn, stillborn, and weaned piglets between the treatment groups. The number of days from weaning to oestrus and the number of oestrous cycles per pregnancy were not influenced by the Na-selenite treatment.

glutathione peroxidase; Se-status; pregnantsows and gilts; weakborn piglets.

Selenium-vitamin E deficiency, which has been shown to cause sudden deaths among fast-growing pigs, used to be a disease of economic importance in Danish herds. The chief clinical manifestations of the disease are dietetic hepatosis and mulberry heart disease. Since 1975, when addition of selenium to swine feed was legalized, cases of dietetic hepatosis have been reduced drastically (Pedersen \& Simesen 1977). However, despite addition

1 Veterinary practitioner, DK-8370 Hadsten.

2 Veterinary practitioner, DK-6990 Ulfborg. 
of selenium to swine feed, the perinatal mortality and the number of weakborn piglets may still be high in herds with a relatively low overall mortality. Selenium treatment of sows and gilts during pregnancy is claimed by veterinarians to reduce this mortality. The present experiment was designed to examine the effect of a single Na-selenite injection during pregnancy on the Se status of the sow and on the viability of the offspring.

\section{MATERIALS AND METHODS}

Selenium treatment of pregnant sows and gilts was conducted as a double-blind placebo-controlled study in 5 commercial herds with a varying degree of perinatal mortality. A total of 350 sows and gilts (Danish Landrace (L), Yorkshire (Y) and LandraceYorkshire crosisbreeds (LY and LYL)) were included in the experiment. At 3-6 weeks before farrowing the animals were injected once intramuscularly with either Na-selenite $(0.05 \mathrm{mg}$ Se per kg bodyweight) or placebo (physiological saline). Immediately before the injection, blood samples were taken from the anterior vena cava into heparinized tubes from $22-26$ randomly selected animals in Herds Nos. 1-4. In Herd No. 5 all sows and gilts were blood-sampled. The same animals were blood-sampled once again at 3-6 weeks after farrowing. Selenium status was evaluated through determination of blood glutathione peroxidase (GSH-Px) activity, (Jensen 1977, Simesen et al. 1982) and GSH-Px activity was determined on whole blood by the method described by Agergaard \& Jensen (1982). In each herd the following observations were recorded: total number of piglets born, number of liveborn, stillborn, and weaned piglets, age at weaning, number of days from weaning to oestrus, number of oestrous cycles per pregnancy. Sows that were not culled were served in their first oestrus.

Sows and gilts were fed a barley-soybean diet supplemented with $0.1 \mathrm{mg}$ Se per $\mathrm{kg}$, consistently with current regulations. The total selenium content in the diet was calculated to be about 0.15 mg per kg.

Statistical analyses were performed in accordance with the Statistical Analysis System described in USA User's Guide (SAS Institute Inc. 1982). Analysis of variance was performed by the general linear model (GLM) procedure with herd, breed, parity, and treatment as independent variables. The effect of treatment was determined within herds. 
The model was:

$$
\begin{aligned}
& \mathbf{y}_{\mathrm{ijklm}}=\mu+\mathrm{b}_{\mathrm{i}}+\mathrm{n}_{\mathrm{j}}+\mathrm{h}_{\mathrm{k}}+\mathrm{t}_{\mathrm{l}}+\mathrm{t}_{\mathrm{kl}}+\mathrm{e}_{\mathrm{ijklm}} \text {, where } \\
& \mathbf{y}_{\mathrm{ijklm}}=\text { individual observation for independent trait } \\
& \mu=\text { mean value of trait } \mathrm{y} \\
& b_{\mathrm{i}}=\text { effect of breed, } \quad \mathrm{i}=1,2 \\
& \mathrm{n}_{\mathrm{j}}=\text { effect of parity } \mathrm{j}=1 . .5 \\
& \mathrm{~h}_{\mathrm{k}}=\text { effect of herd } \mathrm{k}=1 . .5 \\
& t_{1}=\text { effect of treatment } \quad l=1,2 \\
& t_{k l}=\text { effect of treatment within herd } \\
& \mathbf{e}_{\mathrm{ijklm}}=\text { residual effect }
\end{aligned}
$$

For the number of liveborn and stillborn piglets another GLM procedure was performed, with the total number of piglets born included among the independent variables of the model. A corresponding adjustment of the number of weaned piglets was made by including the number of liveborn piglets in the model.

A possible effect of treatment on the number of oestrous cycles per pregnancy was tested by a chi-square analysis (Dunn 1964).

\section{RESULTS}

The mean parity and the breed distribution in the 2 treatment

\begin{tabular}{|c|c|c|c|c|c|}
\hline & Herd No. 1 & Herd No. 2 & Herd No. 3 & Herd No. 4 & Herd No. 5 \\
\hline \multicolumn{6}{|l|}{ Placebo } \\
\hline Parity $(\bar{x})$ & 2.5 & 3.4 & 4.3 & 3.6 & 2.8 \\
\hline Total No. & 52 & 54 & 22 & 18 & 25 \\
\hline $\mathrm{L}, \mathrm{Y}$ & 20 & 7 & 15 & 16 & 4 \\
\hline LY, LYL & 32 & 47 & 7 & 2 & 21 \\
\hline \multicolumn{6}{|l|}{ Na-selenite } \\
\hline Parity ( $\bar{x})$ & 3.1 & 3.6 & 3.8 & 4.0 & 3.2 \\
\hline Total No. & 41 & 53 & 26 & 28 & 31 \\
\hline $\mathrm{L}, \mathrm{Y}$ & 11 & 5 & 19 & 19 & 6 \\
\hline LY, LYL & 30 & 48 & 7 & 9 & 25 \\
\hline
\end{tabular}
groups within each herd are listed in Table 1. In Herds Nos. 1, 2 and 5 crossbreeds were predominant, whereas Herds Nos. 3 and 4 mostly had purebred Landrace and Yorkshire. Herd No. 1 had

T a ble 1. Mean parity $(\bar{x})$ and breed distribution in the placeboand Na-selenite groups within the 5 herds. Breeds comprise Danish Landrace and Yorkshire (L, Y) and the crossbreeds (LY and LYL). The total number of sows and gilts within each group and herd is indicated. 
the lowest mean parity. In this herd there were $40 \%$ gilts whereas in the other herds this percentage ranged from 10 to $25 \%$.

In table 2 the GSH-Px activity per liter of erythrocytes before and after treatment is indicated for the individual herds and for the total of herds. The values are least-square means (LS-means) \pm standard error of the mean (s.e.m.). LS-mean values were adjusted for breed and parity.

Within herds, there was before the injection, no significant difference in GSH-Px activity between the 2 treatment groups. Older sows (more than 4 litters) showed a weak increase in GSH$\mathrm{Px}$ activity as compared with younger sows $(\mathrm{P}<0.05)$. There were only minor differences in Se status among the breeds, but a variation among the herds was seen. Thus, Herds Nos. 2 and 5 showed a higher GSH-Px activity than the rest of the herds $(\mathrm{P}<0.0001)$.

T a ble 2. GSH-Px activity ( $\mu$ kat/l erythrocytes) before treatment and after farrowing in the individual herds and in the total of herds. All values are least-square means \pm s.e.m. adjusted for breed and parity.

The number $(n)$ of sows and gilts is indicated.

\begin{tabular}{|c|c|c|c|c|c|c|}
\hline & Herd No. 1 & Herd No. 2 & Herd No. 3 & Herd No. 4 & Herd No. 5 & Total \\
\hline \multicolumn{7}{|c|}{ Before treatment } \\
\hline $\mathrm{n}$ & $\begin{array}{c}1276 \pm 58 \\
25\end{array}$ & $\begin{array}{l}17.64 \pm 60 \\
26\end{array}$ & $\begin{array}{l}1212 \pm 61 \\
22\end{array}$ & $\begin{array}{c}1375 \pm 64 \\
24\end{array}$ & $\begin{array}{l}1683 \pm 43 \\
56\end{array}$ & $\begin{array}{c}1518 \\
153\end{array}$ \\
\hline \multicolumn{7}{|c|}{ After farrowing } \\
\hline $\begin{array}{c}\text { Placebo } \\
\text { n }\end{array}$ & $\begin{array}{c}1486 \pm 94 \\
11\end{array}$ & $\begin{array}{c}1514 \pm 87 \\
13\end{array}$ & $\begin{array}{c}1299 \pm 108 \\
8\end{array}$ & $\begin{array}{r}1226 \pm 101 \\
11\end{array}$ & $\begin{array}{l}1749 \pm 66 \\
24\end{array}$ & $\begin{array}{r}1455 \\
67\end{array}$ \\
\hline $\begin{array}{c}\text { Na-selenite } \\
n\end{array}$ & $\begin{array}{c}1284 \pm 109 \\
9\end{array}$ & $\begin{array}{c}1658 \pm 89 \\
13\end{array}$ & $\begin{array}{c}1302 \pm 111 \\
8\end{array}$ & $\begin{array}{c}1431 \\
10\end{array}$ & $\begin{array}{c}1855 \pm 60 \\
29\end{array}$ & $\begin{array}{c}1506 \pm 42 \\
69\end{array}$ \\
\hline
\end{tabular}

After farrowing, differences in Se status between the 2 treatment groups in each herd were non significant. Herds Nos. 2 and 5 showed a higher GSH-Px activity than the rest of the herds $(\mathrm{P}<0.05)$. Overall, Landrace and Yorkshire sows and gilts had a higher activity than the crossbreeds $(P<0.001)$, whereas the age of the sows (parity) did not seem to influence the Se status.

The total number of piglets born, the numbers of liveborn, stillborn, and weaned piglets, the number of days from weaning to oestrus, and the age at weaning are given in Table 3. The LS means were corrected for breed and parity. After adjustment for 
T a b l e 3. Total number of piglets born, number of liveborn, stillborn, and weaned piglets, number of days from weaning to oestrus, and age at weaning, as recorded for the two treatment groups in each herd and in the total of herds. All values are least-square means \pm s.e.m. adjusted for breed and parity.

\begin{tabular}{|c|c|c|c|c|c|c|}
\hline & Herd No. 1 & Herd No. 2 & Herd No. 3 & Herd No. 4 & Herd No. 5 & Total \\
\hline \multicolumn{7}{|c|}{ Total No. of piglets born } \\
\hline Placebo & $10.8 \pm 0.3$ & $10.4 \pm 0.4$ & $10.3 \pm 0.5$ & $11.2 \pm 0.6$ & $11.3 \pm 0.5$ & $10.8 \pm 0.2$ \\
\hline Na-selenite & $10.0 \pm 0.4$ & $11.4 \pm 0.4$ & $10.7 \pm 0.5$ & $11.4 \pm 0.5$ & $11.2 \pm 0.4$ & $10.9 \pm 0.2$ \\
\hline \multicolumn{7}{|c|}{ Liveborn piglets } \\
\hline Placebo & $9.9 \pm 0.3$ & $10.0 \pm 0.3$ & $9.5 \pm 0.5$ & $10.5 \pm 0.6$ & $10.2 \pm 0.5$ & $10.0 \pm 0.2$ \\
\hline Na-selenite & $9.2 \pm 0.4$ & $10.8 \pm 0.3$ & $10.0 \pm 0.4$ & $10.8 \pm 0.4$ & $10.2 \pm 0.4$ & $10.2 \pm 0.2$ \\
\hline \multicolumn{7}{|c|}{ Stillborn piglets } \\
\hline Placebo & $0.9 \pm 0.2$ & $0.4 \pm 0.2$ & $0.6 \pm 0.2$ & $0.5 \pm 0.3$ & $1.2 \pm 0.2$ & $0.7 \pm 0.1$ \\
\hline Na-selenite & $0.6 \pm 0.2$ & $0.6 \pm 0.2$ & $0.7 \pm 0.2$ & $0.6 \pm 0.2$ & $1.0 \pm 0.2$ & $0.7 \pm 0.1$ \\
\hline \multicolumn{7}{|c|}{ Weaned piglets } \\
\hline Placebo & $8.9 \pm 0.3$ & $8.9 \pm 0.3$ & $8.9 \pm 0.5$ & $8.8 \pm 0.5$ & $9.1 \pm 0.4$ & $8.9 \pm 0.2$ \\
\hline Na-selenite & $8.3 \pm 0.3$ & $9.9 \pm 0.3$ & $8.9 \pm 0.4$ & $9.0 \pm 0.4$ & $9.4 \pm 0.4$ & $9.1 \pm 0.2$ \\
\hline \multicolumn{7}{|c|}{ Weaning to oestrus (days) } \\
\hline Placebo & $7.9 \pm 0.9$ & $6.9 \pm 1.0$ & $6.4 \pm 1.4$ & $10.2 \pm 1.6$ & $6.4 \pm 1.4$ & $7.6 \pm 0.6$ \\
\hline Na-selenite & $9.9 \pm 1.1$ & $6.2 \pm 1.0$ & $8.4 \pm 1.3$ & $5.7 \pm 1.2$ & $6.5 \pm 1.2$ & $7.3 \pm 0.5$ \\
\hline \multicolumn{7}{|c|}{ Age at weaning (days) } \\
\hline Placebo & $28.2 \pm 0.7$ & $35.1 \pm 0.7$ & $39.9 \pm 1.1$ & $44.4 \pm 1.2$ & $34.3 \pm 1.0$ & $36.4 \pm 0.4$ \\
\hline Na-selenite & $28.4 \pm 0.7$ & $35.4 \pm 0.7$ & $40.9 \pm 1.0$ & $42.8 \pm 1.0$ & $35.0 \pm 0.9$ & $36.5 \pm 0.4$ \\
\hline
\end{tabular}

the total number of piglets born and the number of liveborn piglets there was no difference between the 2 treatment groups in any of the herds.

The age at weaning varied from herd to herd, in Herd No. 1 the piglets were weaned at 28 days of age, in the rest of the herds at $35-44$ days.

In Herd No. 4 efficiency control showed a relatively high number of days from weaning to oestrus before the experiment started. After treatment the Na-selenite-treated group of sows and gilts in this herd had a significantly lower number of days from weaning to oestrus $(P<0.01)$ than the placebo group. The mean number of oestrous cycles per pregnancy ranged from 1.0 to $\mathbf{1 . 1 4}$ per sow in the 5 herds. A chi-square test showed that there was no difference between the 2 treatment groups in number of sows having more than 1 oestrous cycle per pregnancy.

Crossbreeds had a greater number of liveborn piglets than purebred Landrace and Yorkshire $(\mathrm{P}<0.01)$. Older sows got a 
greater number of liveborn, stillborn, and weaned piglets than did gilts. Purebred Landrace and Yorkshire sows had more days from weaning to oestrus than crossbreeds $(P<0.01)$. Gilts and young sows were served at 8-9 days after weaning, whereas older sows were served at $6-7$ days $(P<0.01)$. Differences in the age at which the piglets were weaned and in the number of oestrous cycles per pregnancy were not related to breed or number of litters.

Overall, 22 and 20 animals were culled in, respectively, the placebo and the Na-selenite group. Within herds there was no significant difference in culling rate between the 2 treatment groups.

\section{DISCUSSION}

The notion that selenium treatment might reduce perinatal mortality has not been verified by this experiment. The results confirmed the preliminary observations by Jensen et al. (1983) that the number of liveborn, stillborn, and weaned piglets was not influenced by the treatment. Neither was there any influence on the selenium status during lactation.

Before treatment with Na-selenite or placebo GSH-Px activity within the herds varied within a range previously determined in pigs supplied with $0.1 \mathrm{mg}$ Se per $\mathrm{kg}$ feed. A weak relation between age and Se status was demonstrated, which might explain the relatively low mean GSH-Px activity in Herd No. 1, in that this herd had a high percentage of gilts.

Although during lactation most of the herds had a slightly higher GSH-Px activity in the Na-selenite group than in the placebo group, this difference was not significant and the Se status in the Na-selenite group was almost the same as before treatment. This might be due to the influence of nutrition during pregnancy and lactation, the requirement for selenium around parturition and onset of lactation possibly being increased as sompared with the requirement during pregnancy.

A breed-related influence on the Se status was seen, in that purebred Landrace and Yorkshire had a relatively higher Se status than the crossbreeds. Despite breed variation, Herds Nos. 3 and 4, which mostly had pure breeds, showed the lowest GSH-Px activity of all the herds.

On the whole there was no difference between the 2 treatment groups in numbers of liveborn, stillborn, and weaned piglets. This 
result does not agree with the work of Mihailovic et al. (1982) who found that pregnant sows fed a diet supplemented with selenium and vitamin $\mathbf{E}$ had a significantly lower number of stillborn piglets per litter than the control sows; also, the birthto-weaning mortality in the supplemented group was only half of what it was in the control group.

Nielsen et al. (1979) reported that high dietary levels of Se and vitamin $\mathrm{E}$ were not significantly associated with litter size, which is in accordance with the present work. On the other hand, they found that low dietary levels were followed by increased piglet mortality. The lack of agreement between the reported results may be due to differences in the pre-experimental Se status of the animals.

In Herd No. 4 the weaning-to-oestrus period was significantly reduced in the Na-selenite group. Efficiency control revealed that the number of unproductive feeding days in this herd was relatively high before the experiment started. The age at weaning varied from 28 to 44 days and was not related to treatment.

The finding that the number of liveborn piglets was higher in crossbreeds than in purebred Landrace and Yorkshire, and that the number of piglets born increased with the age of the sow, is consistent with the results of "The Field Testing of Production Systems" comprising a great number of sow herds (Jorsal 1984).

\section{CONCLUSION}

In the experiment reported above, selenium treatment of pregnant sows and gilts fed a barley-soybean diet with a total selenium content of about $0.15 \mathrm{mg}$ per $\mathrm{kg}$ feed did not influence the number of liveborn, stillborn, and weaned piglets. Nor was any effect observed on the number of days from weaning to oestrus or on the number of oestrous cycles per pregnancy.

\section{ACKNOWLEDGEMENTS}

Thanks are due to Dr. S. E. Jorsal, the Institute for Internal Medicine, for help in handling the data, and to Dr. K. Christensen, the Department of Animal Genetics, Royal Veterinary and Agricultural University, Copenhagen, for statistical advice. 


\section{REFERENCES}

Agergaard, N.\& P. Thode Jensen: Procedure for blood glutathione peroxidase determination in cattle and swine. Acta vet. scand. 1982, 23, 515-527.

Dunn, O. J.: Basic Statistics: A primer for the biomedical sciences. J. Wiley and Sons Inc., New York 1964, p. 112-126.

Jensen, A. Mikél, P. Thode Jensen \& K. Vinther: Effect on perinatal mortality of selenium injection to sows and gilts: A preliminary study. Fifth Int. Conf. on Production Disease in Farm Animals, Sweden 1983, p. 370-373.

Jensen, P. Thode: Glutation peroxydase og selen-vitamin E mangel hos svin. (Glutathione peroxidase and selenium-vitamin $\mathrm{E}$ deficiency in pigs). Nord. Vet.-Med. 1977, 29, 166-171.

Jorsal, S. E.: Morbiditet hos søer. (Morbidity in Sows). Thesis, Copenhagen 1984, $118 \mathrm{pp}$.

Mihailović, M., A. Pavlović, P. Radetić, M. Vlatković \& V. Tomić: Influence of feed supplementation with selenium and vitamin $E$ on glutathione peroxidase activity and reproduction in pigs. Acta veterinaria (Beograd) 1982, 32, 275-282.

Nielsen, H. E., V. Danielsen, M. G. Simesen, G. Gissel-Nielsen, W. Hjarde, T. Leth \& A. Basse: Selenium and vitamin E deficiency in pigs. Acta vet. scand. $1979,20,276-288$.

Pedersen, K. B.\& M. G. Simesen: Om tilskud af selen og vitamin E-selen mangelsyndromet hos svin. (Feed supplementation with selenium in relation to the vitamin E-selenium deficiency syndrome in pigs). Nord. Vet.-Med. 1977, 29, 161-165.

SAS Institute Inc.: SAS User's Guide: Basics and Statistics, 1982 Edition. Cary, NC: SAS Institute Inc., 1982, 1507 pp.

Simesen, M. G., P. Thode Jensen, A. Basse, G. Gissel-Nielsen, T. Leth, V. Danielsen \& H. E. Nielsen: Clinico-pathologic findings in young pigs fed different levels of selenium, vitamin $E$ and antioxidant. Acta vet. scand. 1982, 23, 295-308.

\section{SAMMENDRAG}

Seleninjektion til sфer og gylte - effekt på spædgrisedødelighed.

Selenbehandling af drægtige søer og gylte blev udført som et dobbelt blindfors $\varnothing \mathrm{g}$ i 5 besætninger med ialt 350 søer og gylte af Dansk Landrace, Yorkshire og Landrace-Yorkshire krydsninger fodret med en byg-sojaskrå foderblanding tilsat $0,1 \mathrm{mg}$ Se pr. kg. Behandlingen blev foretaget $3-6$ uger $f \varnothing r$ faringen som en enkelt intramuskulær injektion med enten Na-selenit $(0,05 \mathrm{mg}$ Se pr. $\mathrm{kg})$ eller placebo. Blodpr $\varnothing$ ver blev udtaget umiddelbart f $\varnothing \mathrm{r}$ behandlingen og igen $3-6$ uger efter faringen til vurdering af selenstatus. Der blev foretaget registrering af produktionsresultaterne i besætningerne.

Før behandlingen var der ingen forskel på Se status $i$ de to behandlingsgrupper inden for besætningerne; men der blev konstateret 
en variation mellem besætningerne. Efter faringen var der kun ubetydelige forskelle på Se status i behandlingsgrupperne; men variationen mellem besætningerne forblev stor.

Som helhed var der ingen effekt af Na-selenit injektionen, idet der ingen forskel var på antallet af levendef $\varnothing$ dte, dødfødte og fravænnede grise mellem behandlingsgrupperne. Na-selenit injektionen påvirkede heller ikke antallet af dage fra fravænningen til første løbning eller antallet af løbninger pr. drægtighed. I en enkelt besætning var perioden fra fravænning til løbning signifikant kortere i Na-selenitgruppen end i kontrolgruppen.

(Received July 5, 1984).

Reprints may be requested from: A. Mikél Jensen, the State Veterinary Serum Laboratory, Bülowsvej 27, DK-1870 Copenhagen V, Denmark. 